\title{
The Effect of Cash Turnover, Receivable Turnover, and Inventory Turnover Towards Profitability of Consumer Goods Companies in Indonesia
}

\author{
Ertia Nursanti Eryatna*, Nurafni Eltivia, Kuni Utami Handayawati \\ Accounting Management, Accounting Department \\ State Polytechnic of Malang \\ Malang, Indonesia \\ *Ertia.nursanti20@gmail.com,nurafni.eltivia@polinema.ac.id, Kuniutamih@yahoo.com
}

\begin{abstract}
This research aimed to find out the influence of cash turnover, receivable turnover, and inventory turnover toward profitability of consumer goods companies listed in Indonesia Stock Exchange in the period of 2016-2018 with total population of 51 companies. Sampling technique used in this study was purposive sampling and the number of samples obtained were as many as 21 companies. Methods of data analysis used in the study was multiple regression using SPSS 20 assistance. The result showed that cash turnover partially does not have significant effect on profitability. Receivable turnover and inventory turnover partially have significant effect on profitability. While cash turnover, receivable turnover, and inventory turnover simultaneously have significant effect on profitability.
\end{abstract}

Keywords—cash turnover, receivable turnover, inventory turnover, profitability

\section{INTRODUCTION}

Profitability is important and necessary for a company to survive and remain attractive to investors and analysts. According to Sartono [1], profitability is a company's ability to make profit related to sales, total assets, and capital. High profitability will support company's operational activities. It is impossible for a business to survive for a significant amount of time without making profit. therefore, measuring a company's profitability, both current and future, is critical in evaluating the company.

There are several measures of profitability, such as Return On Investment (ROI), Return On Asset (ROA), and Return On Equity (ROE). Profitability in this study is measured using Return On Assets (ROA). According to Harggave [2], return on assets (ROA) is an indicator of how a company generates profit is relative to its total assets. ROA gives a manager, investor, or analyst an idea as to how efficient a company's management is at using its assets to generate earnings. Return on assets is used to see the extent to which the investment invested is able to provide a return on profits follows what is expected based on assets owned [3].
A company's profitability is influenced by some factors that should be recognized by the financial manager in order to maximize profit. One of the factors is Working Capital. Working Capital is the synonym of current assets. Financial manager should have a good ability to manage the amount of working capital that is in accordance with the needs of the company. Working capital that is too high will cause a lot of idle funds and lead the company to suffer losses due to the suboptimal use of funds, while lack of working capital will disrupt the operational activities of company.

The efficiency of Working Capital Management has a big role in measuring a company's profitability. Working Capital Management is a business strategy designed to ensure that a company operates efficiently by monitoring and using its current assets and liabilities for the best performance. Wachowicz [4] stated that 3 main components associated with working capital are cash, account receivable, and inventory. The needs of working capital used in company's operational activities can be seen through each component of working capital's turnover such as cash turnover, receivable turnover, and inventory turnover.

The object of this research is consumer goods companies listed in Indonesia Stock Exchange. Every year, the growth of Consumer goods industry in Indonesia shows a significant improvement since it has a strong connection to basic human needs of daily consumption. Data from Central Statistics Agency (BPS) shows that the growth of the Consumer goods industry was the highest recorded at 18.98 percent in the first quarter of 2019, where the number rose significantly compared to the same period last year which was recorded at 7.46 percent and also increased from the acquisition of 8.73 percent in 2018 .

\section{LITERATURE REVIEW}

\section{A. Financial Statement}

According to Paramasivan [5], financial statement is an official document of the firm, which explores the entire 
financial information of the firm. The main aim of the financial statement is to provide information and understand the financial aspects of the firm. Hence, preparation of the financial statement is important as much as the financial decisions. Financial statement is the summary of the accounting process, which provides useful information to both internal and external parties.

Financial statement generally consists of two important statements including income statement or profit and loss account, and balance sheet or position statement. Apart from that, the business concern also prepares some of the other parts of statements, which are very useful to the internal purpose such as statement of changes in owner's equity, and statement of changes in financial position.

\section{B. Financial Statement Analysis}

According to Ehrhardt and Brigham [6], Financial statement analysis involves comparing a firm's performance with that of other firms in the same industry and evaluating trends in the firm's financial position over time. Managers use financial analysis to identify situations needing attention, potential lenders use financial analysis to determine whether a company is creditworthy and stockholders use financial analysis to help predict future earnings, dividends, and free cash flow.

\section{Techniques of Financial Statement Analysis}

Financial statement analysis is interpreted mainly to determine the financial and operational performance of the business concern. A number of methods or techniques are used to analyze the financial statement of the business concern. The following are the common methods or techniques, which are widely used by the business concern [5]:

1) Comparative Statement Analysis: Comparative statement analysis is an analysis of financial statement at different period of time. This statement helps to understand the comparative position of financial and operational performance at different period of time.

2) Trend Analysis: Trend analysis helps to understand the trend relationship with various items, which appear in the financial statements. These percentages may also be taken as index number showing relative changes in the financial information resulting with the various period of time.

3) Common Size Analysis: Common size analysis is one of the simplest methods of financial statement analysis, which reflects the relationship of each and every item with the base value of $100 \%$.

4) Ratio Analysis: Ratio analysis is a commonly used tool of financial statement analysis. Ratio is a mathematical relationship between one number to another number. Ratio is used as an index for evaluating the financial performance of the business concern.

\section{Working Capital}

Working capital is described as the capital which is not fixed but the more common uses of the working capital is to consider it as the difference between the book value of current assets and current liabilities. Working Capital is another part of the capital which is needed for meeting day to day requirement of the business concern. For example, payment to creditors, salary paid to workers, purchase of raw materials etc., normally it consists of recurring in nature. It can be easily converted into cash. Hence, working capital is also known as short-term capital.

According to the definition of Mead, Baker, and Malott, working capital means current assets. According to the definition of Genestenberg, working capital means current assets of a company that are changed in the ordinary course of business from one form to another, for example, from cash to inventories, inventories to receivables, and receivables to cash. Wachowicz [4] explains there are 3 main components associated with working capital including: Cash, Account receivable, and inventory.

\section{E. Cash Turnover}

Cash turnover is a comparison between sales and the average cash amount. Cash turnover rate is a measure of the efficiency of cash use carried out by the company. Cash turnover is a measure of the efficiency of cash used by companies because the cash turnover rate describes the speed of return of cash invested in working capital [7]. Cash turnover is the ability of cash to generate income so that it can be seen how many times the cash revolves in one period. The following formula can be used to determine cash turnover [8]:

$$
\begin{gathered}
\text { Cash Turnover Ratio }=\frac{\text { Net sales }}{\text { Average Cash Balance }} \\
\text { Average Cash Balance }=\frac{\text { beginning cash }+ \text { ending cash }}{2}
\end{gathered}
$$

\section{F. Receivable Turnover}

According to Warren, et al. in Amanda [9], Account receivable turnover is the relationship between net sales and receivables, calculated by dividing net sales by net receivables on average. The higher the accounts receivable turnover, the better. otherwise, the slower the receivable turnover, the worse. The receivable turnover rate depends on the payment terms provided by the company.

The following formula can be used to calculate receivable turnover [8]:

$$
\begin{gathered}
\text { Receivable Turnover Ratio }=\frac{\text { Net sales }}{\text { Average Net Account Receivable }} \\
\text { Average Cash Balance }=\frac{\text { beginningreceivable }+ \text { ending receivable }}{}
\end{gathered}
$$




\section{G. Inventory Turnover}

According to Suharli [10], Inventory turnover determines how many times inventory is sold or replaced with new inventory in a year, and provides several measurements regarding the liquidity and ability of a company to convert its inventory into money appropriately.

According to Weygandt, Kimmel, and Kieso [11], Inventory turnover measures the number of times on average the inventory is sold during the period. Its purpose is to measure the liquidity of the inventory. Inventory turnover can be computed by using the formula below:

$$
\text { Inventory Turnover }=\frac{\text { Net sales }}{\text { Average Inventory }}
$$

$$
\text { Average Inventory }=\frac{\text { beginning Inventory }+ \text { ending Inventory }}{2}
$$

\section{H. Profitability}

According to Sartono [1], profitability is the company's ability to make profit related to sales, total assets, and capital. High profitability will support the company's operational activities. There are several measures of profitability, including: Return On Investment (ROI), Return On Asset (ROA), and Return On Equity (ROE). Profitability in this study is measured using Return On Assets (ROA).

According to Hargave [2], Return on assets (ROA) is an indicator of how profitable a company is relative to its total assets. ROA gives a manager, investor, or analyst an idea as to how efficient a company's management is at using its assets to generate earnings. The following formula can be used to measure profitability [12]:

$$
\mathrm{ROA}=\frac{\text { Net Income }}{\text { Total Assets }}
$$

\section{Formulation of Hypotheses}

The result of research conducted by Lestari [13], and Rizki [8] stated that cash turnover partially had positive and significant effect on profitability. Based on the theory and previous research, the hypothesis of this study can be formed as follows:

$\mathrm{H}_{1}$ : Cash turnover partially has significant effect on profitability.

The result of research conducted by Sariningsih and lestari [13] stated that receivable turnover partially had positive and significant effect on profitability. Based on the theory and previous research, the hypothesis of this study can be formed as follows:

$\mathrm{H}_{2}$ : Receivable turnover partially has significant effect on profitability.

The result of research conducted by Sariningsih and Umniati [14] stated that inventory turnover partially had positive and significant effect on profitability. Based on the theory and previous research, the hypothesis of this study can be formed as follows:

$\mathrm{H}_{3}$ : Inventory turnover partially has significant effect on profitability.

The result of research conducted by Sariningsih and Lestari [13] stated that receivable turnover partially had positive and significant effect on profitability. Based on the theory and previous research, the hypothesis of this study can be formed as follows:

$\mathrm{H}_{4}$ : Cash turnover, receivable turnover, and inventory turnover simultaneously have significant effect on profitability.

\section{METHODS}

Determination of the sample was determined using tpurposive sampling method. According to Sugiyono [15], purposive sampling is a sampling technique with certain consideration. The criteria of purposive sampling used in this study was determined as follows:

- Consumer goods companies listed in Indonesia Stock Exchange in the period of 2016-2018

- Consumer goods Companies published complete data of financial statement in the period of 2016-2018.

- Consumer goods companies indicated profit on the financial statement in the period of 2016-2018

Based on data from Indonesia Stock Exchange official website (www.idx.com), it was known that the population of consumer goods companies are 51 companies. After using the purposive sampling method, 21 companies were obtained. The analysis technique used multiple linear regression methods, with the previous classical assumption test required in the model. Hypothesis testing is done using the test of the coefficient of determination ( $\mathrm{R}$ - square), partial test (T-test), and simultaneous test (F Test).

\section{RESULTS}

From the results of the analysis using SPSS, the following multiple linear regression equations were obtained

$\mathrm{Y}=6,579+0,001 \mathrm{X} 1+0,408 \mathrm{X} 2+1,872 \mathrm{X} 3$

Information :

Y : Profitability

$\mathrm{X} 1$ : Cash turnover.

X2 : Receivable Turnover

X3 : Inventory Turnover

The multiple regression model is explained as follows:

- profitability has value of 6,579 with the condition of cash turnover, receivable turnover, and inventory turnover assumed as constant. 
- If cash turnover increases by one unit, profitability will increase by 0,001 with the condition of receivable turnover and inventory turnover assumed as constant.

- If receivable turnover increases by one unit, profitability will increase by 0,408 with the condition of cash turnover and inventory turnover assumed as constant.

- If inventory turnover increases by one unit, profitability will increase by 1,872 with the condition of cash turnover and receivable turnover assumed as constant.

\section{A. Classical Assumption Test for Multiple Linear Regression}

1) Normality Test: normality test is carried out by graph analysis and one sample kolmogorov smirnov in standardized residual value using a significant level $\alpha$ of 0.05 with total data (N) of 63. If the value of asymptotic significance $>0.05$, then data is normal. unstandardized residual of all variables shows asymptotic significance of 0.289 that is bigger than significance level $\alpha$ of 0.05 . therefore, the null hypothesis can be accepted that the data of this research meets the assumption of normal distribution.

2) Multicollinearity Test: This test is carried out in order to see whether the resulting regression model has a correlation among independent variables (X). A regression model is said to be free of the multicollinearity problem if the value of Variance Inflation Factor (VIF) on each independent variable is less than 10. Through statistical software, obtained VIF values on 3 independent variables of $1.261 ; 1.265$; and 1.367 which were less than 10 , so it can be concluded that there was no multicollinearity.

3) Heteroscedasticity Test: Heteroscedasticity test is determined using a certain pattern on the distribution of points on the scatterplot between the predicted value of the dependent variable of ZPRED and the residual SPRESID. The result of heteroscedasticity test of this study is that that the plot spreads randomly on the $\mathrm{Y}$ axis and does not form a specific pattern. It can be concluded that the regression model is free from heterosedasticity problems.

4) Autocorrelation Test: Classic assumption of autocorrelation must be fulfilled because if there is a correlation between independent variables, it will have an impact on the regression model where the forecast will not be valid. Examination of the assumption of autocorrelation can be done with the Watson durbin test.

It can be said that there is no correlation among independent variables if the DW (Durbin Watson) value > DU (Durbin Upper). By using a significant level of $\alpha$ of 0.05 , the DU3; $\mathrm{N}$ value is 1.69. Through statistical software, we got DW values of 1.910 which is greater than the DUk; $N$ value. Therefore, it can be concluded that there is no correlation among independent variables.

\section{B. Result of Hypothesis Test}

1) Partial Test (T Test): Partial test (T test) was conducted by comparing tvalue and ttable or significance values. ttable was determined by significance level of 0,05 and degree of freedom Df $=(n-k-1)$ where $n$ is the amount of total samples and $\mathrm{k}$ is the amount of independent variables. The result of $\mathrm{T}$ test can be described as follows:

Using the probability $\alpha$ of 0,05 it can be concluded that:

- Cash turnover has significance value of 0,989 which is greater than probability $\alpha$ of 0,05 . It indicates that cash turnover does not have significant effect on profitability.

- Receivable turnover has significance value of 0,002 which is lower than probability $\alpha$ of 0,005 . It indicates that receivable turnover has significant effect on profitability.

- Inventory turnover has significance value of 0,000 which is lower than probability $\alpha$ of 0,005 . It indicates that inventory turnover has significant effect on profitability.

While using the comparison between $t_{\text {value }}$ and $t_{\text {table, }}$, the value of $t_{\text {table }}$ is determined through statistical table with degree of freedom df $=(n-k-1)=(63-3-1)=59$ and probability $\alpha$ of 0,005 . Therefore, the value of $t_{\text {table }}$ is 2,001 .

$\mathrm{t}_{\mathrm{value}}$ of cash turnover is 0,014 which is lower than the value of $t_{\text {table. Therefore, it can be concluded that cash turnover }}$ does not significantly influence profitability and $\mathrm{H}_{1}$ is rejected.

$\mathrm{t}_{\mathrm{value}}$ of receivable turnover is 3,313 which is higher than the value of $t_{\text {table. }}$. Therefore, it can be concluded that receivable turnover has significant effect on profitability and $\mathrm{H}_{2}$ is accepted.

$t_{\text {value }}$ of inventory turnover is 3,373 which is higher than the

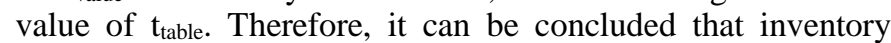
turnover has significant effect on profitability and $\mathrm{H}_{3}$ is accepted.

2) Simultaneous Test (F Test): By comparing significance value and significance level, $\mathrm{H} 4$ can be accepted if sig. < 0,05 . The result of this study showed that significance value of independent variables is 0,000 which is lower than significance level of 0,05 . It indicates that cash turnover, receivable turnover, and inventory turnover simultaneously have significant effect on profitability and $\mathrm{H} 4$ is accepted.

While by comparing $\mathrm{F}_{\text {value }}$ and $\mathrm{F}_{\text {table }}, \mathrm{H}_{4}$ can be accepted if $F_{\text {value }}>F_{\text {table. }} F_{\text {table }}$ was determined by significance level of 0,05 and degree of freedom Df $=k ;(n-k)=3 ;(63-3)=3 ; 60$. Hence, the value of $F_{\text {table }}$ according to $F$ distribution table with probability of 0,05 is 2,76 . The value of $F_{\text {value }}$ is 22,269 which is higher than the value of $F_{\text {table. }}$ It can be concluded that cash turnover, receivable turnover, and inventory turnover simultaneously have significant effect on profitability and $\mathrm{H} 4$ is accepted. 
3) Coefficient of Determination $\left(R^{2}\right)$ : The result of this study showed that the value of coefficient of determination $\left(\mathrm{R}^{2}\right)$ in this research is 0,531 . It indicates that the effect of cash turnover, receivable turnover, and inventory turnover toward profitability is $53 \%$ while the remaining $47 \%$ is influenced by other factors that is not used in this research.

\section{DISCUSSION}

\section{A. The Effect of Cash Turnover on Profitability}

Cash turnover is the ability of cash to generate income so that it can be seen how many times the cash revolves in one period. The higher, the better cash turnover ratio because it shows the efficiency of the use of the cash. But, if the cash turnover ratio is too high, it shows that the cash available is too small to do the sales operating. It indicates that cash turnover can affect achievement of company's profitability.

Based on the result of this study, cash turnover partially does not have significant effect on profitability. This can occur because of fluctuating cash development every year. From data collected, cash turnover of a company can be dramatically changed year by year. it did not show a steady increase or decrease but rather than a drastic change, whether the cash turnover was too high or too low in a certain period. In addition, the existence of uncollectible receivables can also result in companies having to cover losses from uncollectible receivables. The company also uses its cash to purchase raw materials which causes cash turnover does not generate profit in a short time. It indicates that companies were less effective in managing their cash so that cash turnover does not have significant effect on profitability.

\section{B. The Effect of Receivable Turnover on Profitability}

Partial test results showed that tvalue of receivable turnover is higher than ttable $(3.313>2.001)$ and the significance value is lower than alpha probability value $(0.002>0.05)$. it means that receivable turnover partially has significant effect on profitability. therefore, $\mathrm{H} 2$ which stated that receivable turnover partially has significant effect on profitability is accepted and $\mathrm{H} 0$ is rejected.

Receivable turnover is a measure used to quantify a company's effectiveness in collecting its receivables in a certain period. It shows how well a company uses and manages the credit extends to customers and how quickly that short-term debt is collected or is paid. The higher receivable turnover, the better as it will increase profitability.

\section{The Effect of Inventory Turnover on Profitability}

Partial test results showed that tvalue of inventory turnover is higher than ttable $(3.373>2.001)$ and the significance value is lower than alpha probability value $(0.000>0.05)$. it means that inventory turnover partially has significant effect on profitability. therefore, $\mathrm{H} 3$ which stated that inventory turnover partially has significant effect on profitability is accepted and $\mathrm{H} 0$ is rejected.
Inventory turnover determines how many times inventory is sold or replaced with new inventory in a year, and provides several measurements regarding the ability of a company to convert its inventory into money appropriately. High inventory turnover rate will decrease the risk of losses due to the rapid sales. when company's sales activity goes well, the profitability earned will increase.

\section{The Effect of Cash Turnover, Receivable Turnover, and Inventory Turnover on Profitability}

The result of simultaneous test (F test) of multiple regression analysis showed that Fvalue of independent variables is higher than Ftable $(22.269>2.76)$ and the significance value is lower than alpha probability value $(0.000$ $>0.05)$. it means that cash turnover, receivable turnover, and inventory turnover simultaneously have significant effect on profitability.

Cash, account receivable, and inventory are included to working capital or current assets of a company. Working capital turnover should revolve effectively in order to maximize profit. The higher working capital turnover, the better as it will increase profitability. Working capital that is too high will cause a lot of idle funds and lead the company to suffer losses due to the suboptimal use of funds, while lack of working capital will disrupt the operational activities of company.

The result of this study is in line with research conducted by Sariningsih and Lestari [13] which stated that cash turnover, receivable turnover, and inventory turnover simultaneously have significant effect on profitability. while this study is not in line with research conducted by Rizki [18] and Amanda [9] which stated that cash turnover, receivable turnover, and inventory turnover simultaneously does not have significant effect on profitability.

\section{MANAGERIAL ASPECT}

Based on the result of research on the effect of cash turnover, receivable turnover, and inventory turnover toward profitability of consumer goods companies in Indonesia, there are several managerial implications as follows:

1) Cash turnover partially does not have significant effect on profitability: It indicates that companies were less effective in managing their cash so that cash turnover does not have significant effect on profitability. Company internal parties are expected to manage cash turnover not to be too low or too high by paying more attention to the budgeting process as it is a key management tool for planning, monitoring, and controlling the Finances of a company. Management should estimate the income and expenditures for a set period of time for the company. Budgeting can serve a number of important purposes such as Monitoring the income and expenditures over the course of a year, Helping to determine if adjustments need to be made in achieving targets and goals, and 
Forecasting income and expenses for projects, including the timing and the availability of income (such as additional grant funds) that will help management in managing cash so that cash turnover will meet the need of the company's operational activities.

2) Receivable turnover partially has significant effect on profitability: It indicates that the ability of a company in collecting its account receivable in certain period holds an important role to maximize profitability. Therefore, Companies must continue to increase receivable turnover by Reviewing credit policies to ensure credit terms and conditions are assessed and issued to customers based on good risk management practices, Ensuring that sales and finance teams are enforcing agreed credit limits for each customer, Improving invoicing processes by using best practice invoice templates and issuing invoices immediately after sales, and Improving overdue collections by systemizing and automating time intensive follow-ups. The faster funds Invested in accounts receivable, the higher profitability will increase.

3) Inventory turnover partially has significant effect on profitability: It indicates that the ability of a company in managing its inventory sold or replaced influences profitability. Company needs to mantain inventory turnover by controlling how long the company needs time to spend inventory in its production process and improving sales. company needs to formulate better marketing strategies to create more demand in the industry and thus, give a push to its sales. These could focus on advertisements or have promotional events and offers. Besides, forecasting techniques can be another way to increase the level of inventory turnover. If companies are able to forecast the demands of the customer correctly, companies need to stock only those items and this will reduce companies' inventory levels, which in turn will increase the inventory turnover ratio. High inventory turnover rate will decrease the risk of losses due to the rapid sales. when company's sales activity goes well, the profitability earned will increase.

4) Cash turnover, receivable turnover, and inventory turnover simultaneously have significant effect on profitability: it indicates that the ability of a company in managing its working capital affects profitability earned. Therefore, company internal parties are expected to maintain working capital turnover and sales that influences company's profitability by paying more attention to the budgeting process, reviewing credit policies to ensure credit terms and conditions are assessed and issued to customers based on good risk management practices in order to maintain receivables turnover ratio, and formulating better marketing strategies to create more demand in the industry and thus, give a push to its sales. Moreover, to improve working capital, most companies aim to shorten their working capital cycle by a faster collection of receivables, minimize inventory cycles and extend payment terms.

\section{CONCLUSION}

This research is intended to find out the effect of cash turnover, receivable turnover, and inventory turnover toward profitability of consumer goods companies in Indonesia. Based on partial test ( $\mathrm{T}$ test) and simultaneous test ( $\mathrm{F}$ test), it can be concluded that:

- Cash turnover partially does not have significant effect on profitability with significance value of 0.989 which is greater than probability $\alpha$ of 0,05 and tvalue of 0.014 which is lower than ttable of 2.001 .

- Receivable turnover partially has significant effect on profitability with significance value of 0.002 which is lower than probability $\alpha$ of 0,05 and tvalue of 3.313 which is lower than ttable of 2.001 .

- Inventory turnover partially has significant effect on profitability with significance value of 0.000 which is lower than probability $\alpha$ of 0,05 and tvalue of 3.373 which is lower than ttable of 2.001

- Cash turnover, receivable turnover, and inventory turnover simultaneously have significant effect on profitability with significance value of 0.000 which is lower than probability $\alpha$ of 0,05 and Fvalue of 22.269 which is higher than Ftable of 2.76

Further research is expected to be able to prove the influence of cash turnover on profitability by expanding the object and research period. Moreover, further research should use more independent variables that might affect profitability that have not been used in this study.

\section{REFERENCES}

[1] A.R. Sartono, Manajemen Keuangan Teori dan Aplikasi. Edisi Keempat.Yogyakarta: BPFE. 2010.

[2] M. Hargrave, Return on Assets-ROA. Retrieved November, 9, p.2019. 2019.

[3] Brighman and Houston, Essentials Of Financial Management. Edisi 11 Buku 1. Salemba Empat. Jakarta. 2010.

[4] C. James, V Horne \& J.M. Wachowicz, Prinsip-prinsip Manajemen Keuangan. Edisi kedua belas. Jakarta: Salemba Empat. 2005.

[5] C. Paramasivan, T. Subramanian, Financial Management. New Delhi: NewAge International. 2009.

[6] M.C. Ehrhardt, E.F. Brigham, Financial Management Theory and Practice. Thirteenth Edition. United States of America: Cengage Learning. 2010.

[7] B. Riyanto, Dasar-Dasar Pembelanjaan Perusahaan. Edisi keempat. Penerbit: BPFE, Yogyakarta. 2011.

[8] M.N. Rizki, “Analysis of Working Capital Turnover Impact toward Profitability and Accounting Implication at PT. Multi Strada Arah Sarana Tbk". The Accounting Journal of BINANIAGA Vol. 02, No. 02. 2017.

[9] R.I. Amanda, "The Impact Of Cash Turnover, Receivable Turnover, Inventory Turnover, Current Ratio And Debt To Equity Ratio On Profitability". Journal of Research in Management Vol. 2, No. 2, 2019, pp. $14-22.2019$. 
[10] M. Suharli, Akuntansi untuk Bisnis Jasa dan Dagang, Edisi Pertama, Yogyakarta: Graha Ilmu. 2006.

[11] J.J. Weygandt, D.E. Kieso, P.D. Kimmel, and A.L. DeFranco, Hospitality financial accounting. John Wiley and Sons. 2008.

[12] Brealey, Myers, Marcus, Dasar-dasar Manajemen Keuangan. Edisi 5. Jilid 1. Jakarta: Erlangga. 2008.

[13] A.P.T. Lestari, Pengaruh Perputaran Kas Perputaran Persediaa Perputaran Piutang terhadap Profitabilitas pada Perusahaan Manufaktur yang Terdaftar di Bursa Efek Indonesia. Yogyakarta: FE UNY. 2017.
[14] R. Umniati, K.H. Titisari, \& Y. Chomsatu, August. "The Influence of Current Ratio, Inventory Turnover Ratio, Cash Turnover and Debt to Equity Ratio Against the Return on Investment in The Production of Industrial Companies Listed on The Stock Exchange Of Malaysia In 2016". In PROCEEDING ICTESS (Internasional Conference on Technology, Education and Social Sciences). 2018

[15] Sugiyono, Statistika untuk Penelitian. Bandung. Bandung: CV. Alfabeta. 2016 